is less likely to break new ground than the biologist starting far behind him in purely chemical equipment. There is pressing need now for a parallel development of bio-physics, not necessarily, or even desirably, as a separate discipline, but by a breaking down of the present artificial educational barriers between physics and physiology, barriers so unworthy of the Greek spirit of which those very names remind us.

I must not stay to speak of still another set of conditions that handicap medical progress. of those biologists who pass on to hospital work and the study of disease as such, many who are among the fittest to make new knowledge in the sphere of clinical medicine are tempted to turn aside from the arduous path of new investigation, either because of the absorbing human interest of professional work or again because of their financial needs or desires.

The mastery over non-living matter which physical science has given us has transformed all the conditions of human life within a century, but the conveniences offered by improved transport and improved communications have brought only super- ficial changes, and it is doubtful whether they have done on the whole greater service or disservice to the happiness and well-being of mankind. Our improved powers of producing wealth, as the whole world is now observing, seem already to have outrun lamentably our powers either of wisely using or even of retaining it. It is better mastery over living matter, and the improvement of the bodily and mental powers of man, that are needed for the real betterment and enrichment of the race. By powers of a kind that we are already in process of gaining by medical research we may hope to transform human life in ways almost unimagined now and to make a new world indeed.

Without entering into dreams of the far future we know that here and now the campaign of medical research is improving our estate. Its progress and success have immediate interest for all of us and the highest claims upon the goodwill of all mankind. It is a campaign to diminish pain, to lessen the waste of human effort and human life, and to enrich and enlarge the powers of the human body and mind.

\title{
York Meeting of the British Association
}

$\mathrm{T}^{\mathrm{H}}$ HE full programme of the York meeting of the British Association is approaching completion, and should be in the hands of members very shortly. A change of practice has been instituted with the view of economy and greater convenience. The " Programme and Daily Timetable" will embody the usual features both of the Association's list of transactions and of the socalled local programme formerly issued by the authorities at the place of meeting. Between these two publications there was always a measure of overlapping; moreover, the local programme was never in the hands of members until their arrival at the meeting. Now, following the practice initiated at last year's centenary meeting, when the whole organisation was centred at Burlington House, it becomes possible to place fuller advance information in the hands of nembers whose intention to attend, and postal addresses, are known.

Another and still more important change of practice with the same objects is initiated this year. It had become the custom, as is well known, for local committees to prepare handbooks for the successive places of meeting. Some of these have become standard reference-books of material value; on the other hand, the series followed no definite plan, and these books, again, were issued only at the meeting, and were sometimes very costly to produce. It is known that they did not always receive from members the attention they deserved: there is a case on record of a copy of the local handbook being seen on a second-hand bookstall in the place of meeting almost immediately after its issue. For the present year, a short "Scientific Survey of York and District" has been prepared by recognised authorities through the London office, with the collaboration of the appropriate sectional officers and the York executive. This also will be issued, so far as possible, to members in advance, and they will thus have the opportunity of priming themselves with information about the locality before they visit it. It is intended afterwards to include this "Survey" in the Annual Report, and if the present issue is found to form a satisfactory model, there will gradually accumulate, as the Association meets in successive centres, a systematic series of local scientific studies.

In these directions, at least, the Association has travelled far from the practice of twenty years ago, when the meeting was announced by a single leaflet, and members were left to find all other information at the meeting itself. Certainly the Association has become more businesslike (if the epithet may be permitted) in the formulation and announcement of its programmes. The main lines of the sectional transactions are laid down at the joint meeting of the organising sectional committees in January. The value of this meeting, which was initiated at the instance of the former general treasurer, the late Dr. E. H. Griffiths, has been, from the point of view of administration, immense, and it is believed to be the general opinion that it offers a most useful occasion for the really hard labourers in the Association's vineyard to keep in personal touch during the interval between the annual meetings.

As a result, the principal features of the meeting were known in broad outline when the "Preliminary Programme" was issued and noticed in NATURE for April 30, p. 642. Not many important corrections are made. The title of Lord Rothschild's presidential address to Section D (Zoology), not then announced, is now known to be "The Pioneer Work of the Systematist". The evening discourses by Sir Arthur Hill and Mr. C. C. Paterson have been transferred from the Exhibition Hall, which is found unsuitable for lanterns and demonstrations, to the less commodious but more 
intimate Co-operative Hall, where, to obviate overcrowding, special tickets will be required (an unusual practice, which members are asked to note). The discussion on the university movement in Yorkshire, originally announced provisionally in Section L (Education), will not take place. For the rest, the full programme in no way falls below its predecessors in general interest. As compared with the York meetings of 1881 and 1906 (and indeed with later meetings) there is to be observed the widening of the tendency of sections to lay out their programmes and group their communications under definite broad headings. This is a movement appreciated by the informed public which it is one of the functions of the Association to address: the method gives a clear view, from year to year, of directions in which the main lines of scientific ad. vancement are being laid down; and if the Association should be tending to leave the highly specialised individual communication to other more specialised media (and probably, on balance, there is such a tendency), the meetings should not on that account become less valuable to scientific workers. As occasions for personal contacts, these meetings are unique. To take a single illustration from the present programme, it is difficult to imagine another organisation which would give opportunity for a joint discussion of common problems between physicists and psychologists.

In the previous article on the York meeting in these pages, it was stated that many points of interest in the neighbourhood would be visited, and that no locality is richer in them. The full programme bears out this statement. In York itself there are all the antiquarian interests of the city. There are the cocoa and chocolate works of Messrs. Rowntree and Messrs. Terry, at both of which special receptions are being arranged. There are the museum, the carriage works, and the signalling school of the London and North Eastern Railway, the scientific instrument works of Messrs. Cooke,
Troughton and Sims, and glass, aircraft, electrical, and other works. Taking a radius from York to the east coast, Hull, Leeds, and the Pennines, there are geological, botanical, zoological, archæological, industrial, and educational interests of the widest variety, of which the various sections which arrange their own excursions will take full advantage. The general excursions, mainly, as usual, on the Saturday, will combine railway and road travel in a manner not without significance when these methods of transport are elsewhere so strongly in opposition; there will also be occasions for relaxation on the River Ouse.

It might have been feared-indeed, it was feared-that the difficulties of the present time might react unfavourably on the attendance at the meeting. It is never known until the meeting itself what amount of local support by way of membership will be forthcoming : it is to be hoped that it will be ample at York. But so far as concerns the attendance of visiting members, as registered from day to day in the London office, there is no evidence of any enforced diminution of interest.

Lastly, these same difficulties, as suggested at the beginning of this article, have dictated economy in the working of the meeting. Traditions expensive to maintain had been handed on from one locality which entertained the Association to the next. The Council was instructed by the General Committee at the centenary meeting last year to review the cost of meetings falling upon local funds, and to suggest measures for its reduction. This has been done. The steps taken in cooperation with the York executive will not affect the Association's own funds in the direction of saving - they may, indeed, have a contrary result. But they will render the Association this year, and, it is to be hoped, in future, a less exacting guest than it used to be, and that without any diminution in the scientific value of its proceedings.

\section{Obituary}

Sir Richard Threlfall, G.B.E., F.R.S. No one who knew Threlfall is likely to forget humour, his gift of vivid expression, his energy, his driving force, his power of telling a good story and of making a good speech, together with his massive frame, made an impression not easily effaced. Those who knew him most intimately knew that besides all this he was the staunchest and most helpful of friends, one on whose help they could rely in good times or bad, and whose death has taken from them a prop on which they had often leaned.

Threlfall was born at Hollowforth, a village near Preston, on Aug. 14, 1861, and in due time went to Clifton. Here his tastes soon became apparent; explosives were his first love, and legends about his adventures in practical chemistry still float about; one of these is that he conceived the idea of felling trees by the aid of dynamite and tried it on a young fir tree just outside the school, with the result that the tree was shot through the window of the school laboratory. Once when he was working at home during the Easter holidays, in a small laboratory which his father had fitted up, he had an explosion which blew off the third and little finger of his left hand and a good deal of the hand at the back of them, as well as the top joints of the right thumb and index finger. It was characteristic of him that before being driven into Preston to have his wounds dressed, he asked his mother to get a piece of wood and put it between his teeth so as to keep his mouth open. He said if he did get lockjaw he was not going to be starved to death as well. In spite of the loss of half his fingers he became one of the best manipulators and glass-blowers of his time, and wrote a book on laboratory arts. He was in the Rugby XV. at Clifton, and also shot for the School.

He left Clifton in 1880 and entered Caius College,

No. 3276, VoL. 130] 